\title{
The effect of competence and organization culture to employee performance with motivation as the mediation variable in the Directorate General of Fiscal balance-Ministry of Finance, Indonesia
}

\author{
Acep Dedi Supriadi; Suharto; Sodikin \\ Master of Management Program, Faculty of Economics, Krisnadwipayana University, \\ Indonesia \\ e-mail correspondence : acepsd@gmail.com
}

\begin{abstract}
High employee performance can be achieved if all elements within the organization can be well integrated. Increased employee competence, application of organizational culture and employee motivation are part of the elements or variables that affect an employee performance. This research aims to determine and analyze the influence of competence and organizational culture on employee performance through motivation as a variable mediation. The population in this research is all Civil Servant of Directorat General of Fiscal Balance (DGFB) which amounted to 426 people. Sampling method is Simple Ramdom Sampling (SRS) with the number of respondents as much as 80 employees calculated based on Slovin Formula. Data collection techniques in this study are literature study and questionnaire. Data were analyzed by path analysis model by using SPSS. The first results of this researh showed that the competence and organizational culture simultaneously had a positive and significant effect on motivation. Furthermore, based on the results of partial tests, competence have a positive but not significant effect on motivation, while the influence of organizational culture on motivation is positive and significant.The second result shows that the competence, organizational culture, and motivation have positive and significant effect on employee performance. Furthermore, based on the results of partial tests, competence and organizational culture show the same results that have a positive and significant effect on employee performance, while motivation effects on employee performance although still positive but not significant.
\end{abstract}

Keywords: Competence, Organizational culture, Motivation, Employee performance.

\section{INTRODUCTION}

Ministry of Finance is a ministry in Indonesia that hold responsibility on finance and state assets. One of the important functions of the finance ministry is to formulate and implement fiscal decentralization policies. Furthermore, the function is implemented by an echelon unit I namely the Directorate General of Fiscal Balance (DGFB).

To ensure the functionality is well implemented, DGFB requires employees who are able to work professionally, responsibly, with integrity and high performance. Recognizing the important role of DGFB employees, the Minister of Finance conveys his support and expectations to all DGFB employees submitted during the Final Meeting of the 2015 Leadership, to continuously improve the professionalism of work through increased competence, innovation, breakthrough steps in the formulation of 
fiscal decentralization policy and the improvement of formulation allocation of transfer funds to the regions.

The role of human resources in various management literature is said to be very important for the organization. This is in line with the opinion Tangkilisan (2002) which states that humans are the most important element in the organization, because humans always play an active and dominant role in every organization. Humans are planners, actors, and at the same time determining the achievement of organizational goals. Thus the human resources of an organization is required to have the ability in carrying out its duties and functions, has strong motivation to participate in all activities of the organization, able to work effectively and efficiently, and ultimately can provide the best performance to support the achievement of organizational goals.

In any organization, employees who are considered high performers are employees who are able to contribute greatly to the success of the organization in realizing its vision, mission, and objectives. It is therefore an obligation that the organization needs to create a condition that supports all its employees to work well, maintain cohesiveness, and always synergize to show its best performance for the achievement of personal goals and organization.

Performance of employees is basically influenced by several conditions, namely the condition that comes from within the employee (individual factors) and conditions that come from outside the employee (situational factors). Individual factors include health, sex, experience, and psychological characteristics of employees, namely personality, motivation, goal orientation and ability of employees. The external factors include leadership, social relations, organizational culture, education and training. Performance is the achievement of work obtained by an employee in performing his duties in accordance with the responsibilities given to him. Performance is divided into two, namely individual performance and organizational performance. Individual performance is the result of employee work in terms of quality and quantity based on predetermined work standards, while organizational performance is a combination of performance achieved by each individual and group performance where the individual is incorporated.

According to Prawirosentono (2008), performance is the work achieved by a person or group of people within the organization, in accordance with their respective powers and responsibilities in order to achieve the objectives of the organization legally, not violating the law, morals and ethics. While Gibson et al. (1996) in Trinaningsih (2007) argues that employee performance is a measure that can be used to define the comparisons of task performance results, responsibilities given by the organization over a given period and can be used to measure work performance or organizational performance. Meanwhile, the opinion of Hasibuan (2003) that work performance is the work achieved by a person in carrying out the tasks assigned to him based on his skills, experience, seriousness, and timing of completion.

Performance of employees is basically influenced by several conditions, namely the condition that comes from within the employee (individual factors) and conditions that come from outside the employee (situational factors). Individual factors include health, sex, experience and psychological characteristics of employees consisting of personality, motivation, goal orientation and ability of employees. The external factors include leadership, social relations, organizational culture, education and training.

The variables to be analyzed influence on employee performance in this research is competence, organizational culture, and motivation. The first variable to be analyzed is the competency variable. In general, competence is defined as skills and abilities. 
Competence comes from the word "competent" which means skillful or skilled. In the context of human resource management, the term competence refers to the attributes or characteristics of a person who makes himself successful in the job. Many people often use the term competence as the ability to perform. It can be understood that the success of an employee in completing the work is strongly influenced by the skills, knowledge, attitude, behavior, and ability.

Competence also involves the individual's authority to perform the task and make decisions according to his or her role in the organization based on his or her expertise, knowledge, and abilities. Rivai (2009) said that the competencies of individual employees must be able to support the implementation of organizational strategy and able to support any changes made by management. In other words, the competence of an individual can support a team-based work system. Thus, to realize the success of programs that have been established by an organization, then every employee is required to have the required competency standards.

According to Roe (2001), competence is the ability to perform a task or role adequately, the ability to integrate knowledge, skills, attitudes and personal values, and the ability to build knowledge and skills based on experiences and lessons learned. While Spencer and Spencer in Palan (2007) argue that competence shows the underlying characteristics of behavior that, describe the motives, personal characteristics, self-concept, values, knowledge or skills that cause the employee to perform excellently in the workplace. Meanwhile Wibowo (2007) argues that competence is an ability to perform a job or task based on skills and knowledge and supported by work attitude according to the guidance of the work.

Competence according to Echols and Shadil (1983) is skill or ability. Meanwhile, according Purwadarminta (1982), competence is as authority or power to determine or decide something. As a public organization, DGPK has the most dominant resource of employees with all competencies both hardskills and softskills. Competence of employees in a public organization is needed so that employees can work professionally in carrying out their duties and responsibilities, so that the demands of society can be met and future challenges can be faced. This is in line with Spencer's opinion in Moeheriono (2012), that the relationship between employee competence and performance is very close and very important, the relevance is strong and accurate.

Based on the above explanation, it can be concluded that the competence is the mastery of a set of knowledge, skills, values and attitudes that direct an employee to think, work and act in accordance with the profession.

The second variable to be analyzed is the organizational culture variable. Culture according to Wibowo (2007) is a systematic human activity, passed from generation to generation through various learning processes in order to create a particular way of living that best suits the environment where he lived. Meanwhile, the word "organization" comes from the Greek "organon" meaning instrument or instrument. When a person sets up an organization, the ultimate goal is not the organization itself but rather that he and everyone involved can achieve other goals more easily and more effectively.

Organizational culture is a system of spreading trust and values that develop within an organization and provide direction for the behavior of its members. Organizational culture can be the main instrument in creating organizational competitive advantage, only when organizational culture can answer or address environmental challenges quickly and appropriately. 
According to Wirawan (2007), organizational culture is the norm, values, assumptions, beliefs, philosophy, and organizational habits developed over long periods by the founders, leaders, and members of the organization and then socialized and taught to new members so they can imitate and organize it in organizational activities, and ultimately can influence the mindset, attitudes, and behavior of employees in producing products, serving consumers, and achieve organizational goals. While Victor Tan in Sole (2007) gives the opinion that organizational culture is a norm consisting of a belief, attitude, core values, and behavior patterns that people do in the organization. Meanwhile, Robbins (2001) argues that organizational culture is a shared value system shared by its members and this becomes the organizational differentiator with other organizations.

Organizational culture is also called corporate culture or work culture because it cannot be separated with the performance of human resources. The stronger the corporate culture, the stronger the achievement drive. Culture is a very important factor in improving organizational effectiveness. Organizational culture can be a major competitive competitiveness tool, when organizational culture supports organizational strategy and can answer or address environmental challenges quickly and appropriately.

Organizational culture according to Robins (1999) is a shared value system within an organization that determines the maturity of an employee in acting on behalf of his organization so that the organization's goals can be achieved. Organizational culture for civil servants has been regulated in the Regulation of the Minister of Administrative Reform and Bureaucracy Reform No. 25 of 2002 on Guidelines for Work Culture for State Apparatus.

The regulation states that every ministry / institution and local government is required to build a work culture that supports the implementation of bureaucratic reform in the hope that the work culture can encourage the change of attitude and behavior of officials and employees in their respective environment so that in the end the performance of government organization can be more improving over time. This is in line with Kottler and Hesket's opinion in Andreas Lako (2004) that organizational culture has a positive effect on long-term performance improvement.

The third variable to be analyzed is motivation. Employee motivation in an organization can be viewed as simple but can also be a complex problem if ignored. This is because, basically, humans are easy to be motivated by giving what their desires, needs, and expectations. Motivation can also be used as an incentive for employees to complete the tasks assigned to them.

In the scope of research, motivation variable functioned as a measuring tool to see whether an employee has a good work motivation to complete the task based on job description. If an employee's work motivation decreases it will negatively affect the rhythm of work, on the contrary if an employee has a good working motivation of the performance will be good too. While in the scope of implementation, work motivation serves to determine whether an employee still has a strong impetus to work well or just the opposite after so long the employee worked in the company.

According to Hasibuan (2007), motivation is the provision of a driving force that creates a passion for an employee, so that they will cooperate, work effectively and integrate with all their efforts to achieve satisfaction. While Robbins (2006) argues that motivation as a process that explains the intensity, direction, and persistence of effort to achieve a goal. Motivation can be interpreted as an integral part of industrial relations in the framework of the process of coaching, development, and direction of human resources within a company. Meanwhile, Mc's opinion. Donald in Sudarwan Danim 
(2004) about motivation is a change of energy in a person characterized by the emergence of "feeling" and preceded by a response to the existence of a goal.

Motivation is a provision of encouragement or stimulation to a person so that he or she works voluntarily or without being forced (Saydan, 2000). Referring to the theory of Maslow with the theory of hirarchy of needs that motivation is influenced by the impulse of physiological needs, the impetus of the need for work safety, the impulse of social needs, the impulse of the need for appreciation, and the impulse of selfactualization needs. Some of the routine activities carried out by the DGPK in providing motivation to employees are organizing seminars, technical guidance, or motivational training by inviting professional experts in the field of leadership, hypnotherapy, and behavior analysis.

Based on the above explanation, the purpose of this research is to understand more deeply the relationship or influence of competence variable, organizational culture, and motivation to employee performance at Directorate General of Fiscal Balance (DGFB) - Ministry of Finance. The results of this study are expected to be useful for banyka parties. For the student of this research result is expected to be the next research reference, for the government organization is expected the result of this research is also useful as input for the leadership in establishing the strategy about the improvement of employee performance.

\section{RESEARCH METHODS}

\section{Research design}

Based on the research objectives as previously mentioned, this research is an explanatory research that explains the causality relationship between: (1) competency variable and organizational culture on employee motivation, (2) competency variable, organizational culture, and motivation to employee performance, and (3) variable competence and organizational culture on employee performance through motivation as a mediation variable. This study was conducted through the submission of questionnaires to employees selected randomly as respondents at the Directorate General of Fiscal Balance (DGFB) Ministry of Finance.

\section{Population and sample}

The population in this research is all 427 employees of DGFB. Furthermore, by using the Slovin formula, the researchers set the number of samples (respondents) as much as 80 employees, selected by random sampling.

\section{Technique data processing}

Data processing is a process that must be done first before the researcher conducts hypothesis-testing research. Data processing is intended to convert the raw data of the questionnaire into meaningful data to solve the research problem. The steps of data processing conducted by researchers are: 1) the first step to test the quality of data through validity test and reliability test. Validity tests are needed to measure whether questions in the questionnaire can measure what we want to measure (Ghozali, 2002). Reliability tests are needed to gauge whether questionnaire questions can be answered by the respondent consistently at all times; 2) Transformation of data to convert the data of questionnaire originally ordinal scale into interval scale, through Successive Interval Method - MSI (Rasyid, 1998). 


\section{Classical assumption test}

Prior to carrying out the path analysis, the researcher must perform the classical assumption test first to provide assurance that the equation of the regression model obtained has accuracy in estimation, unbiased and consistent. The classical assumption test done in this research is Normality Test, Multicollinearity Test, Linearity Test, Autocorrelation Test, and Heteroscedasticity Test.

\section{Data analysis technique}

The analysis model used in this research is path analysis. Path analysis according to Rutherford (1993) is a technique for analyzing the causal relationships that occur in multiple regressions if the independent variables affect the dependent variable not only directly, but also indirectly. In fact, path analysis is similar to regression analysis because both are causality analysis models. The difference is path analysis using variable mediator (intermediary) while regression analysis there is no variable mediator.

The type of variables in the path analysis model consists of 3 (three), namely independent variables, mediation variables, and the dependent variable. In this research, competence and organizational culture become independent variable; motivation becomes mediation variable, and employee performance become dependent variable.

Thus in this research there are 2 (two) structural equations, that are: 1) Structural Equations I consists of two independent variables (competence and organizational culture) that influence the motivation as an independent variable; 2) Structural Equations II consists of Tree independent variables (competence, organizational culture, and motivation) that influence the employee performance as an independent variable and motivation as an intervening variable (mediation).

\section{RESULTS AND DISCUSSION}

\section{Data quality test result}

\section{a. Validity test}

All questions in the questionnaire about competence, organizational culture, motivation, and employee performance based on research data are valid. This means that questions or statements in the questionnaire can be said precisely and meticulous in measuring the questionable problem without causing any bias. The correlation coefficient value (r-count) of each item score with total score is entirely above the ttable value (0.1852). The test uses two-tailed assumptions with the number of respondents $(\mathrm{n})=80$, and the degree of freedom is $80-2=78(\mathrm{df})$, the table $\mathrm{t}$ value is 0.1825 .

\section{b. Reliability test}

All questions in the questionnaire about competence, organizational culture, motivation, and employee performance are valid, as it can express consistent answers to statements in the questionnaire without causing any bias. This can be seen from the correlation coefficient (r. count) of each item question score with the total score entirely whose value is above the t-table value $(0.1852)$. The test uses two-tailed assumptions with the number of respondents $(\mathrm{n})=80$, and the degree of freedom is $80-2=78(\mathrm{df})$, the table $\mathrm{t}$ value is 0.1825 . 
Table 1. Instrument reliability test results

\begin{tabular}{lcc}
\hline \multicolumn{1}{c}{ Variable/Instrumen } & $\begin{array}{c}\text { Value of alpha } \\
\text { cronbach }\end{array}$ & Interpretation \\
\hline Competence $\left(\mathrm{X}_{1}\right)$ & 0,825 & Reliable \\
Organizational Culture $\left(\mathrm{X}_{2}\right)$ & 0,883 & Reliable \\
Motivation $\left(\mathrm{X}_{3}\right)$ & 0,725 & Reliable \\
Employee Performance $\left(\mathrm{X}_{4}\right)$ & 0,918 & Reliable \\
\hline
\end{tabular}

Source: data obtained from SPSS results

\section{Classical assumption test result}

a. Normality test

The normality test aims to test whether in a linear regression model, the dependent variable and the independent variable both have a normal distribution or not. Normality test in this research will use One Sample Kolmogorov-Smirnov with $5 \%$ significance level.

Table 2. Normality test based on Kolmogorov-Smirnov Z

\begin{tabular}{lcc}
\hline \multicolumn{1}{c}{ Variable/Instrumen } & $\begin{array}{c}\text { Value of alpha } \\
\text { cronbach }\end{array}$ & $\begin{array}{c}\text { Interpretation } \\
\text { If }>0,05 \text { (Norm. Dist) } \\
\text { If }<0,05 \text { (Not Norm. Dist) }\end{array}$ \\
\hline Competence $\left(\mathrm{X}_{1}\right)$ & 0,240 & Normally distributed \\
Organizational Culture $\left(\mathrm{X}_{2}\right)$ & 0,075 & Normally distributed \\
Motivation $\left(\mathrm{X}_{3}\right)$ & 0,044 & Not normally distributed \\
Employee Performance $\left(\mathrm{X}_{4}\right)$ & 0,036 & Not normally distributed \\
\hline
\end{tabular}

Source: data obtained from SPSS results

Based on the Kolmogorov-Smirnov One-Sample Test, variable Competency (X1) and organizational culture (X2) indicate Asymp Sig. (2-tailed)) more than 0.05, so it is said to be normally distributed. While the variable motivation (X3) and employee performance (X4) indicates Asymp value. Sig. (2-tailed) less than 0.05, so it is said to be abnormal distribution.

\section{b. Multicollinearity (Collinearity Statistic)}

Multicollinearity test aims to test whether in the regression model found a correlation between dependent variables (free). A good regression model should not be correlated among the independent variables (Ghozali, 2008). Multicollinearity test is done by finding the value of VIF (Variance Inflation Factor) or tolerance value.

Table 3. Result of multicollinearity test

\begin{tabular}{lcl}
\hline \multirow{2}{*}{ Variable/Instrumen } & \multicolumn{2}{c}{ Collinearity Statistics } \\
\cline { 2 - 3 } & Tolereance & VIF \\
\hline Competence $\left(\mathrm{X}_{1}\right)$ & 0.366 & 2.733 \\
Organizational Culture $\left(\mathrm{X}_{2}\right)$ & 0.272 & 3.683 \\
Motivation $\left(\mathrm{X}_{3}\right)$ & 0.438 & 2.283 \\
\hline
\end{tabular}

Source: data obtained from SPSS results

Tolerance Values of Competence variable, organizational culture, and motivation greater than 0.10 . Meanwhile the VIF value of those variables is smaller than 10.00. Therefore, it can be concluded that there is no multicollinearity. 


\section{c. Linearity test}

Linearity test aims to determine whether two variables have a linear relationship significantly or not. Linearity test in this research is done through $\mathrm{F}$ test by looking at significance value and F-count.

Table 4. Results of linearity test by ANOVA Table between independent variables to the dependent variable (performance employees)

\begin{tabular}{lcc}
\hline \multicolumn{1}{c}{ Variable/Instrumen } & $\begin{array}{c}\text { Significancy of } \\
\text { Linearity }\end{array}$ & $\begin{array}{c}\text { Interpretation } \\
\text { If }<0,05 \text { (Linear) } \\
\text { If }>0,05 \text { (Not Linear) }\end{array}$ \\
\hline Competence $\left(\mathrm{X}_{1}\right)$ & 0.000 & Linear \\
Organizational Culture $\left(\mathrm{X}_{2}\right)$ & 0.000 & Linear \\
Motivation $\left(\mathrm{X}_{3}\right)$ & 0.000 & Linear \\
\hline Source: data obtained from SPSS results & &
\end{tabular}

Based on the Results of Linearity Test, variables Competency (X1), organizational culture (X2), and motivation indicate significance of linearity less than 0.05 , so it is said to be linear.

\section{d. Autocorrelation test}

Autocorrelation test aims to test whether in the linear regression model there is a correlation between the confounding errors in period $t$ with the intruder error in period t-1 (previous). Durbin Watson value approach on test output (model summary) compared with table value at 5\% significance detected Autocorrelation test.

Durbin Watson (DW) value in this research is 2,203. Furthermore, the value is compared with Durbin Watson (DW) Table, both the upper value (DU) and the lower value (DL). Based on the Durbin Watson Table at $\mathrm{K}=3$ and $\mathrm{N}=80$, the DL value is 1.5600 and the DU value is 1.7153 . Thus it can be concluded that the regression that occurs between the independent variable and the dependent variable there is no autocorrelation either positive or negative.

\section{e. Heteroscedastisity Test}

Heteroscedasticity test is one of the classical assumption assays to be performed on linear regression. In conducting heteroscedasticity test the researchers used SPSS version 20 program to form the Scatterplot chart and Glejser.

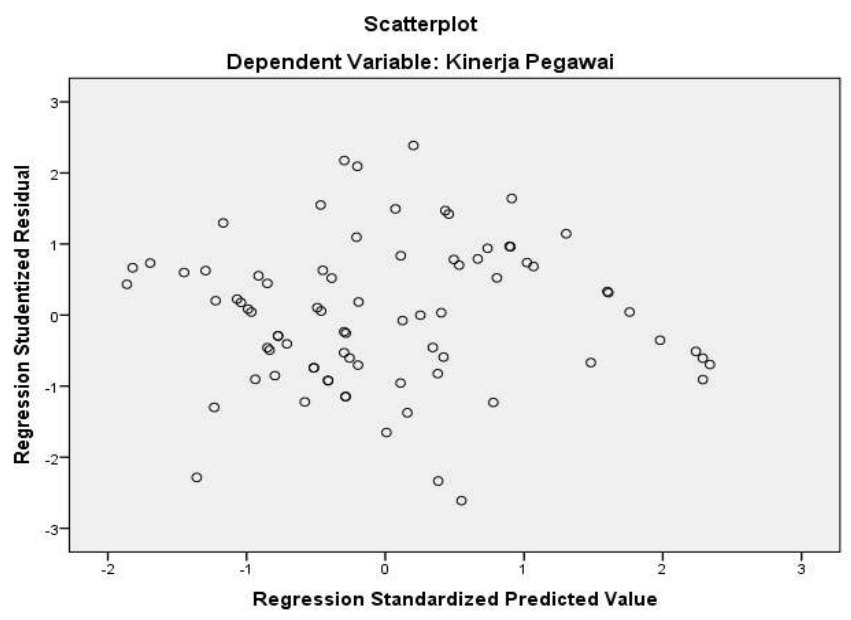

Picture 1. Scatterplot 
Based on the results of the Scatterplot graph output, it appears that the data points spread and did not form a certain pattern that is clear or also does not accumulate at a particular location. Thus it can be concluded that no symptoms of heteroscedasticity.

\section{Analysis of research results} namely:

The path analysis model in this research consists of two structural equations,

(1) $\mathrm{X} 3=0,115 \mathrm{X} 1+0,655 \mathrm{X} 2+\varepsilon 1$ and

(2) $\mathrm{X} 4=0,333 \mathrm{X} 1+0,501 \mathrm{X} 2+0,102 \mathrm{X} 3+\varepsilon 2$

The values of path coefficient for each variable in the structural equation I and II are obtained from the value of standardize coefficient $\beta$ as the table below:

Table 5. Coefficient variable structural equation I

\begin{tabular}{|c|c|c|}
\hline Variable/Instrumen & Standardized Coefficients & Significance \\
\hline Competence $\left(\mathrm{X}_{1}\right)$ &, 115 &, 357 \\
\hline Organizational Culture $\left(\mathrm{X}_{2}\right)$ &, 655 &, 000 \\
\hline
\end{tabular}

Source: data obtained from SPSS results

Table 6. Coefficient variable structural equation II

\begin{tabular}{lcc}
\hline \multicolumn{1}{c}{ Variable/Instrumen } & Standardized Coefficients & Significance \\
\hline Competence $\left(\mathrm{X}_{1}\right)$ &, 333 &, 001 \\
Organizational Culture $\left(\mathrm{X}_{2}\right)$ &, 501 &, 000 \\
Motivation $\left(\mathrm{X}_{3}\right)$ &, 102 &, 240 \\
\hline
\end{tabular}

Source: data obtained from SPSS results

The detailed analysis of research results are as follows:

1. Base on simultaneous test (Test-F) on equation of structure I shows that Competence and organizational culture has a significant influence on motivation of $56.19 \%$ and categorized quite influential, while the remaining $43.81 \%$ influenced by other variables. The significance value of model $\mathrm{I}$ is 0,000 which means significant because it is less than 0.05 and the F-count value 49.378 is much larger than F-table 3.115 .

2. The partial analysis of the direct effect of competence on motivation. Based on The analysis results, that the path coefficient of competence to motivation ( $p 31)$ is 0.115 . This means, there is a positive influence of competence variable on employee motivation, but because the significance value 0.357 greater than 0.05 , then the influence is said to be insignificant and according to Lind (2002) criterion the effect is called quite weak, so it can be ignored or considered to be absent.

3. The partial analysis of the direct effect of organizational culture on motivation. Based on the analysis results, that the path coefficient of organizational culture on motivation ( $p 32)$ is 0.655 . This means, there is a positive influence of competency variable on employee motivation equal to $65.5 \%$. Because the significance value of 0.000 is smaller than 0.05 , so the influence is said to be significant and according to Lind criteria (2002) the effect is called strong.

4. Base on simultaneous test (Test-F) on equation of structure II shows that competence, organizational culture, and motivation together have a strong and significant influence to employee performance variable. Its influence is $75.56 \%$ and 
according to criterion of Lind (2002) categorized as strong relation, while the rest $24.44 \%$ influenced by other variable. The significance value of model II is 0,000 which means significant because less than 0.05 and the F-count value of 78.310 is much larger than F-table 2,725. Meanwhile, partial analysis of the results of this research are as follows:

5. The partial analysis of the direct effect of competency variable to employee performance. Based on the analysis result, that the path coefficient of competence variable on employee performance $(p 41)$ is 0.333 . This means that there is a direct influence of competency variable on employee performance, and because the significance value of 0.001 is smaller than 0.05 , then the influence is said to be significant. This is also in accordance with the opinion of Wirawan (2009) that the competence has a causal relationship to the performance of employees.

6. The partial analysis of the direct effect of organizational culture on employee performance. Based on the analysis result, that the path coefficient of organizational culture on employee performance $(p 42)$ is 0.501 . This means, There is positive influence of organizational culture on employee performances, and because the significance value is 0.000 smaller than 0.05 , hence influence is said significant. The results of this study are in accordance with previous research by Kottler and Hesket in 1992 (in Andreas Lako, 2004: 32) that organizational culture has a positive effect on long-term performance improvement.

7. The partial analysis of the direct effect of motivation variable on employee performance. Based on the analysis result, that the path coefficient of motivation on employee performance ( $p 43)$ is 0.102 . This means that there is a direct effect of the motivation variable on employee performance, and because the significance value is 0.240 larger than 0.05 , then the influence is said to be insignificant. The result shows that motivation variable although still give positive influence $10,2 \%$ to employee performance, but not significant because according to criterion Lind (2002) the influence is classified as very weak so it can be ignored or considered not exist. The results of this study is not in line with previous research by Juliyanawati (2010) which says there is a significant relationship between work motivation on employee performance at PT. Panasonic Gobel Indonesia.

8. The partial analysis of the indirect effect of competency variable on employee performance through motivation as a mediation variable. Based on the analysis result, The Path line coefficient of competence to employee performance through motivation is 0.0117. This means, there is indirectly affect of competence to employees performance through motivation as a variable mediation, but not effective because its direct influence is still greater than its indirect effect.

9. The partial analysis of the indirect effect of organizational culture variable on employee performance through motivation as a mediation variable. Based on the analysis result, The Path coefficient of organizational culture to employee performance through motivation is 0.0668 . This means, there is indirectly affect of competence to employees performance through motivation as a variable mediation, but not effective because its direct influence is still greater than its indirect effect.

10. In addition, this study also shows that motivational variables are less effective as mediators (intermediaries) for competency variables and organizational culture to influence employee performance. It is caused by direct effect of competence variable $(33.3 \%)$ and organizational culture variable $(50.1 \%)$ to employee performance variable still bigger than indirect effect. The indirect effect of competency variable on employee performance through motivation is $1.17 \%$ and organizational culture 
variable is $6.68 \%$. This research implies that the effort to improve employee performance is less effective if all the leaders and employees of DGFB assume that employee motivation is the main factor or variable that should be prioritized rather than the competence and culture of the organization.

\section{CONCLUSIONS AND RECOMMENDATIONS}

\section{Conclusions}

Based on the results of this study can be obtained several conclusions, the first is the competence and organizational culture variables simultaneously have a positive and significant influence on the motivation variable of $56.19 \%$, while the rest of $43.81 \%$ influenced by other variables not included in this study. However, if observed through the partial test results, the competence variable has a positive but not significant influence on the motivation variable, while the influence of organizational culture variable on the motivation variable is positive and significant.

The second conclusion is competence variable, organizational culture, and motivation have positive and significant effect on employee performance equal to $75,56 \%$, while the rest equal to $24,44 \%$ influenced by other variable not included in this research. However, if observed through the results of partial tests, competence and organizational culture variables show the same results that have positive and significant impact on employee performance, while employee motivation variable influence on employee performance is not significant.

\section{Recommendations}

DGFB should always strive to improve employee performance in terms of quality and quantity. Efforts to develop and improve employee performance is mainly done through the implementation of cultural values of the organization Ministry of Finance with better and perfect, as well as increased competence and motivation of employees. To optimize this effort, DGFB must also use other instruments such as compensation that satisfy the sense of justice and prepare a career path that is good for employees so that in carrying out their duties the employees become more enthusiastic and serious. Researchers believe that the results of this study can serve as a reference research in the field of Human Resources Management, especially in the public sector organization.

\section{BIBLIOGRAPHY}

Arikunto, Suharsimi, (2002). Research Procedures A Practice Approach. Revised Edition V. Rineka Cipta: Jakarta.

Cohen, J., and Cohen P. (1983). Applied Multiple Regression / Correlation Analysis for the Behavioral Sciences. 2nd Edition. Lawrence Erlbaum Associates, Inc..

Dessler, Gary. (2006). Human Resource Management. The tenth edition. PT Intan true: Klaten.

Directorat General of Fiscal Balance (DGFB). (2016). Performance Report of Directorate General of Fiscal Balance Ministry of Finance: Jakarta.

Echols, J. and Shadily, Hasan. (1996). Indonesian English Dictionary. PT Gramedia: Jakarta.

Ghozali, Imam (2002). Aplikasi Analisis Multivariate dengan Program IBM SPSS 20. Badan Penerbit Universitas Diponegoro. Semarang

Gordon, Anderson. (1992). Managing Performance Appraisal System: Unitted Kingdom 
Hasibuan, Malayu. (2007). Organization and Motivation. PT. Earth Aksara, Jakarta.

Husein, Umar, (2002). Business Research Methods. PT. Gramedia Pustaka Utama: Jakarta

Ivancevich, J. M. Konopaske R. and Matteson M.T., (2005). Organizational Behavior and Management. Seventh Edition.

Kennaa, E. and Beach, N., (2002). The essense of Human Resource Management. Publisher Budi: Yogyakarta.

Hair, Anderson, Tatham, and Black, (1998). Multivariate Data Analysis, 5th Edition, Prentice Hall: New Jersey.

Hasibuan, (2001). Deputy of Human Resources of the National Development Planning Agency: Jakarta.

Kerlinger F. N and Pedhazur, J.P (1973), Multiple regression in behavioral research, Holt, Rinehart and Winston, Inc.: New York.

Kotter, John P \& James L.Heskett, (2006). Corporate Culture And Performance. Saga: Indonesia.

Li Ching Chun, (1975). Path Analysis: a Primer, The Boxwood Press: California

Mangkunegara, A.A Anwar Prabu. (2002). Management of Human Resources. Teens Rosda Karya: Bandung.

Mathis, Robert L And Jackson, John H. (2002). Human Resource Management. Book 2. Salemba four: Jakarta.

Mulyana, Dedy. (2001). Quantitative Research Methodology. Rosda: Bandung.

Robbins, Stephen P. (2007). Organizational Behavior. Book I. Issue 12. Salemba Four: Jakarta.

Setyawan, Widyantoro. (2012). Understanding the Importance of Values of the Ministry of Finance. Retrieved from http://www.bppk.depkeu.go.id/ on June 4.

Siagian, Sondang P. (2002). Tips to Increase Work Productivity. Rineka Cipta: Jakarta.

Simanjuntak, Payaman J, Prof.Dr, (2005). Performance Management and Evaluation. Faculty of Economics. University of Indonesia: Jakarta.

Syafarudin, Alwi. (2008). Human Resource Management, Strategy of Competitive Advantage. BPFE: Yogyakarta.

Surya, Dharma. (2010). Performance Management, Theory Philosophy and Its Application. Pustaka Pelajar: Yogyakarta.

Uno, B Hamzah. (2009). Motivation \& Measurement Theory, Analysis in the Field of Education. Earth Script: Jakarta. 